\title{
Synthesis of a bis-amino acid that creates a sharp turn
}

Stephen A. Habay and Christian E. Schafmeister

Department of Chemistry, University of Pittsburgh

Pittsburgh, PA 15260 
General: THF was distilled from $\mathrm{Na}$ /benzophenone under $\mathrm{N}_{2} \cdot \mathrm{CH}_{2} \mathrm{Cl}_{2}$ and $\mathrm{CHCl}_{3}$ were distilled from $\mathrm{CaH}_{2}$. Anhydrous methanol was purchased from Aldrich Chemical Company and used directly. $\mathrm{Pb}\left(\mathrm{NO}_{3}\right)_{2}$ was dried by heating in a vacuum oven $\left(95^{\circ} \mathrm{C}, 1\right.$ $\mathrm{mm} \mathrm{Hg}$ ) overnight and stored in a sealed container over anhydrous $\mathrm{CaCl}_{2}$.

Phenylfluorenyl bromide was prepared according to a previously reported procedure (Jamison, T.F., Lubell, W.D., Dener, J.M., Krische, M.J., Rapoport, H. Org. Syn., CV9, 103-106.). All other reagents were used as received unless otherwise noted. All reactions were carried out in flame-dried or oven-dried glassware under $\mathrm{N}_{2}$ atmosphere unless otherwise noted. Column chromatography was performed using ICN Silitech 32$63 \mathrm{D}$ (60 A) grade silica gel and TLC analysis was performed on EM Science Silica Gel $60 \mathrm{~F}_{254}$ plates $(250 \mu \mathrm{m}$ thickness). NMR experiments were performed on either Bruker Advance $300 \mathrm{MHz}$ or Bruker Advance DRX $500 \mathrm{MHz}$ spectrometers. Chemical shifts $(\delta)$ are reported relative to $\mathrm{CDCl}_{3}$ or DMSO- $d_{6}$ residual solvent peaks, unless otherwise noted. If possible, rotational isomers were resolved by obtaining spectra above $100^{\circ} \mathrm{C}$ in DMSO- $d_{6}$ at the below indicated temperatures. IR spectra were obtained on a Nicolet Avatar E.S.P. 360 FT-IR. Optical rotations were obtained on a Perkin-Elmer 241 polarimeter at the indicated temperatures. EI-MS was performed on a Micromass Autospec high resolution mass spectrometer (CEBE geometry). High resolution ESI-MS was performed on a Waters LC/Q-TOF instrument. HPLC analysis was performed on a Hewlett-Packard Series1050 instrument with diode array detector, using a Varian Chrompack Microsorb $100 \mathrm{C}_{18}$ column (5 $\mu \mathrm{m}$ packing, $2.6 \mathrm{~mm}$ x $250 \mathrm{~mm}$ ). HPLC-MS analysis was performed on a Hewlett-Packard Series 1100 instrument with diode array detector, HP $1100 \mathrm{MS}$ detector (ESI), using a Waters Xterra MS $\mathrm{C}_{18}$ column $(3.5 \mu \mathrm{m}$ packing, $4.6 \mathrm{~mm} \times 100 \mathrm{~mm}$ ). Analysis of 2D NMR data was performed using Sparky 3, T.D. Goddard and D.G. Kneller, University of California, San Francisco.
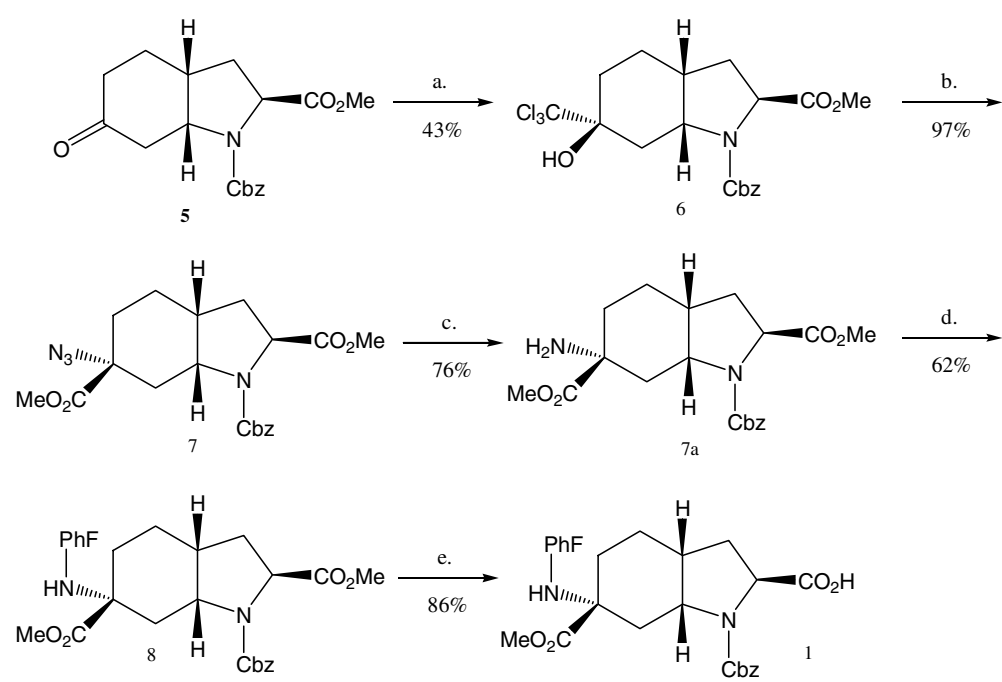

Reagents and Conditions: (a.) $\mathrm{CHCl}_{3}$, LHMDS, THF, $-78^{\circ} \mathrm{C}$, $1 \mathrm{~h}$; (b.) $\mathrm{NaN}_{3}, \mathrm{DBU}, \mathrm{MeOH}, 18$-crown-6, 22h; (c.) Zn, THF:AcOH (1:1), 45min; (d.) PhFBr, Pb(NO$)_{2}$, TEA, DCM, 20h; (e.) LiOH, THF: $\mathrm{H}_{2} \mathrm{O}, 24 \mathrm{~h}$.

Supplemental Scheme 1: Synthesis of (1) 
(2S,4R,7S,9R)-1-benzyl 2-methyl 7-(trichloromethyl) octahydro-7-hydroxyindole1,2-dicarboxylate (6). A solution of ketone (5) $(2.55 \mathrm{~g}, 7.70 \mathrm{mmol})$ in THF $(40 \mathrm{~mL})$ was cooled to $-78^{\circ} \mathrm{C}$ in a dry ice/acetone bath and dry $\mathrm{CHCl}_{3}(1.55 \mathrm{~mL}, 19.25 \mathrm{mmol})$ was added. A $1 \mathrm{M}$ solution of LHMDS in THF $(16.94 \mathrm{~mL})$ was added dropwise over a period of 20 min via a syringe pump. After addition was complete, the reaction was stirred for an additional $1 \mathrm{~h}$ at $-78^{\circ} \mathrm{C}$. The reaction mixture was then poured into a saturated solution of $\mathrm{NH}_{4} \mathrm{Cl}$ and extracted twice with EtOAc $(2 \times 50 \mathrm{~mL})$. The combined organic fractions were dried $\left(\mathrm{Na}_{2} \mathrm{SO}_{4}\right)$, filtered and the solvent removed in vacuo. The remaining residue was then sufficiently purified by flash column chromatography (1:2 EtOAc:hexanes, loading in 1:1 EtOAc:hexanes). The resulting foam from purification was then recyrstallized from EtOAc/hexanes to yield $1.47 \mathrm{~g} \mathrm{(43 \% )}$ of diastereomerically pure (determined by NMR) $(6)$ as small, white granular crystals $\left(\mathrm{mp}=173.8-174.5^{\circ} \mathrm{C}\right)$. $[\alpha]^{22}{ }_{\mathrm{D}}=-32.2\left(c 0.5, \mathrm{CH}_{2} \mathrm{Cl}_{2}\right)$; IR (neat) 3344, 1746, 1685, 1419, 1352, 1291, 1203, 1173, $1024,773 \mathrm{~cm}^{-1}$; ${ }^{1} \mathrm{H}$ NMR $\left(300 \mathrm{MHz}, 105^{\circ} \mathrm{C}\right.$, DMSO- $\left.d_{6}\right) \delta 7.35-7.27(\mathrm{~m}, 5 \mathrm{H}), 5.68(\mathrm{br} \mathrm{s}$, $1 \mathrm{H}), 5.13(\mathrm{br} \mathrm{d}, \mathrm{J}=12.5 \mathrm{~Hz}, 1 \mathrm{H}), 5.02(\mathrm{br} \mathrm{d}, \mathrm{J}=12.5 \mathrm{~Hz}, 1 \mathrm{H}), 4.35(\mathrm{~d}, \mathrm{~J}=8.8 \mathrm{~Hz}, 1 \mathrm{H})$, 4.22-4.15 (m, 1H), $3.59(\mathrm{~s}, 3 \mathrm{H}), 2.60-2.50(\mathrm{~m}, 1 \mathrm{H}), 2.47-2.40(\mathrm{~m}, 1 \mathrm{H}), 2.36-2.21(\mathrm{~m}$, $1 \mathrm{H}), 2.13-1.90(\mathrm{~m}, 2 \mathrm{H}), 1.86-1.76(\mathrm{~m}, 2 \mathrm{H}), 1.70-1.53(\mathrm{~m}, 2 \mathrm{H}) ;{ }^{13} \mathrm{C}$ NMR $(75.4 \mathrm{MHz}$, $\left.\mathrm{CDCl}_{3}\right)(\sim 1: 1$ mixture of rotamers) $\delta 172.8,172.7,154.3,153.8,136.5,136.2,128.4$, $128.3,127.9,127.8,109.0,82.0,81.9,67.1,58.4,58.3,55.5,55.0,52.3,52.1,33.8,32.9$, 32.5, 32.0, 31.9, 30.7, 25.5, 25.4, 21.0; HR-MS (EI) calculated for $\mathrm{C}_{19} \mathrm{H}_{22} \mathrm{Cl}_{3} \mathrm{NO}_{5}$ 449.0564, found 449.0569.

(2S,4R,7R,9R)-1-benzyl-2,7-dimethyl-7-azido octahydroindole-1,2,7-tricarboxylate (7). To a solution of alcohol (6) $(1.05 \mathrm{~g}, 2.33 \mathrm{mmol})$ in $46 \mathrm{~mL}$ of anhydrous methanol, was added sodium azide $(454 \mathrm{mg}, 6.99 \mathrm{mmol})$ and a catalytic amount of 18 -crown-6 (10mg). DBU $(1.75 \mathrm{~mL}, 11.65 \mathrm{mmol})$ was added slowly and the reaction allowed to stir for $22 \mathrm{~h}$. The reaction mixture was diluted with diethyl ether $(100 \mathrm{~mL})$, washed with $\mathrm{NH}_{4} \mathrm{Cl}(50 \mathrm{~mL})$, dried $\left(\mathrm{Na}_{2} \mathrm{SO}_{4}\right)$, filtered and concentrated. The oily residue was then purified by flash column chromatography (1:2 EtOAc:hexanes) to yield azido ester (7) (939mg, 97\%) as a yellow oil. $[\alpha]^{21} \mathrm{D}=-16.9\left(c 5, \mathrm{CH}_{2} \mathrm{Cl}_{2}\right)$; IR (neat) $2105,1726,763$, $697 \mathrm{~cm}^{-1} ;{ }^{1} \mathrm{H}$ NMR $\left(300 \mathrm{MHz}, 105^{\circ} \mathrm{C}\right.$, DMSO- $\left.d_{6}\right) \delta$ 7.35-7.28 (m, 5H), $5.10(\mathrm{~d}, \mathrm{~J}=$ $12.2 \mathrm{~Hz}, 1 \mathrm{H}), 5.02(\mathrm{~d}, \mathrm{~J}=12.2 \mathrm{~Hz}, 1 \mathrm{H}), 4.35(\mathrm{br} \mathrm{d}, \mathrm{J}=7.8 \mathrm{~Hz}, 1 \mathrm{H}), 4.13-4.05(\mathrm{~m}, 1 \mathrm{H})$, $3.76(\mathrm{br} \mathrm{s}, 3 \mathrm{H}), 3.59$ (br s, $3 \mathrm{H}), 2.58-2.50(\mathrm{~m}, 1 \mathrm{H}), 2.42-2.29(\mathrm{~m}, 2 \mathrm{H}), 1.99-1.92(\mathrm{~m}, 1 \mathrm{H})$, $1.85-1.78(\mathrm{~m}, 1 \mathrm{H}), 1.75-1.65(\mathrm{~m}, 3 \mathrm{H}), 1.65-1.58(\mathrm{~m}, 1 \mathrm{H}) ;{ }^{13} \mathrm{C} \mathrm{NMR}\left(75.4 \mathrm{MHz}, \mathrm{CDCl}_{3}\right)$ $(\sim 1: 1$ mixture of rotamers) $\delta 172.7,172.4,170.6,170.3,154.0,153.5,136.1,128.2$, 128.1, 127.7, 127.6, 127.6, 127.3, 66.8, 66.6, 64.8, 58.3, 55.1, 54.7, 52.6, 52.5, 52.0, 51.8, 34.2, 33.6, 33.3, 32.3, 31.0, 27.9, 27.4, 21.5; HR-MS (EI) calculated for $\mathrm{C}_{20} \mathrm{H}_{24} \mathrm{~N}_{2} \mathrm{O}_{6}$ (M$\mathrm{N}_{2}$ ) 388.1634 , found 388.1635 .

(2S,4R,7R,9R)-1-benzyl-2,7-dimethyl-7-amino octahydroindole-1,2,7-tricarboxylate (7a). To a solution of azido ester (7) $(2.51 \mathrm{~g}, 6.03 \mathrm{mmol})$ in $20 \mathrm{~mL}$ of $1: 1 \mathrm{AcOH}: \mathrm{THF}$ was added powdered $\mathrm{Zn}(250 \mathrm{mg}, 10 \mathrm{wt} \%)$ in one portion. The suspension was allowed to stir for approximately $45 \mathrm{~min}$. Evolution of bubbles of $\mathrm{N}_{2}$ gas was observed during this time period. (Note: If the reaction is sluggish, an additional $5 \mathrm{wt} \%$ of $\mathrm{Zn}$ can be added to achieve complete reaction.) The $\mathrm{Zn}$ was then filtered from the reaction mixture and washed with a copious amount $(100 \mathrm{~mL})$ of ethyl acetate. The diluted solution was 
transferred to a separatory funnel and carefully washed several times with saturated $\mathrm{NaHCO}_{3}$. The combined bicarbonate portions were washed twice with fresh portions of EtOAc $(20 \mathrm{~mL})$. The combined organic fractions were dried $\left(\mathrm{Na}_{2} \mathrm{SO}_{4}\right)$, filtered and the solvent removed in vacuo. Non- polar impurities were removed by adsorption of the residue onto a small plug of silica and elution first with 1:2 EtOAc:hexanes followed by 9:1 $\mathrm{CHCl}_{3}: \mathrm{MeOH}$. Finally, the solvent was removed to provide the amine product (7a) $(1.80 \mathrm{~g}, 76 \%)$ as a clear, viscous oil. This compound was used without further purification. $[\alpha]^{20}{ }_{D}=-5.5\left(c 0.8, \mathrm{CH}_{2} \mathrm{Cl}_{2}\right)$; IR (neat) $3365,3298,1705,1408,1203,1122$, $1009,768,691 \mathrm{~cm}^{-1} ;{ }^{1} \mathrm{H}$ NMR $\left(300 \mathrm{MHz}, 110^{\circ} \mathrm{C}\right.$, DMSO-d $)(\sim 3: 1$ mixture of rotamers $)$ $\delta$ 7.33-7.27 (m, 5H), 5.11-5.05 (m, 2H), 4.79 (br s, 2H), 4.32 (br d, J = 8.3 Hz, 1H), 4.25$4.19(\mathrm{~m}, 0.25 \mathrm{H}), 4.19-4.08(\mathrm{~m}, 0.75 \mathrm{H}), 3.68$ (br s, 3H), 3.59 (br s, 2.25H), 3.54 (br s, $0.75 \mathrm{H}), 2.82(\mathrm{dd}, \mathrm{J}=13.0,5.6 \mathrm{~Hz}, 0.25 \mathrm{H}), 2.53-2.49(\mathrm{~m}, 0.75 \mathrm{H}), 2.35-2.25(\mathrm{~m}, 2 \mathrm{H}), 1.90-$ $1.75(\mathrm{~m}, 2 \mathrm{H}), 1.72-1.49(\mathrm{~m}, 3 \mathrm{H}), 1.39(\mathrm{dd}, \mathrm{J}=12.9,11.1 \mathrm{~Hz}, 0.75 \mathrm{H}), 1.23(\mathrm{dd}, \mathrm{J}=12.7$, $11.0 \mathrm{~Hz}, 0.25 \mathrm{H}) ;{ }^{13} \mathrm{C}$ NMR $\left(75.4 \mathrm{MHz}, \mathrm{DMSO}-d_{6}\right)(\sim 1: 1$ mixture of rotamers $) \delta 173.7$, $173.5,172.7,172.4,153.5,152.9,136.7,136.6,128.3,128.2,127.7,127.2,126.9,65.9$, 58.1, 57.8, 57.3, 54.9, 54.7, 52.2, 52.0, 51.9, 35.5, 34.5, 33.6, 32.6, 31.5, 30.5, 29.3, 29.1, 21.3, 21.2; HR-MS (EI) calculated for $\mathrm{C}_{20} \mathrm{H}_{26} \mathrm{~N}_{2} \mathrm{O}_{6} 390.1791$, found 390.1790.

(2S,4R,7R,9R)-1-benzyl-2,7-dimethyl-7-(9-phenyl-9H-fluoren-9-ylamino) octahydroindole-1,2,7-tricarboxylate (8). To a solution of amine $(1.80 \mathrm{~g}, 4.61 \mathrm{mmol})$ in dry $\mathrm{CH}_{2} \mathrm{Cl}_{2}(10 \mathrm{~mL})$, was added dry $\mathrm{Pb}\left(\mathrm{NO}_{3}\right)_{2}(1.10 \mathrm{~g}, 3.32 \mathrm{mmol})$ and triethylamine $(771 \mu \mathrm{L}, 5.53 \mathrm{mmol})$. A solution of $\mathrm{PhFBr}(1.48 \mathrm{~g}, 4.61 \mathrm{mmol})$ in $\mathrm{CH}_{2} \mathrm{Cl}_{2}(5 \mathrm{~mL})$ was added dropwise. The reaction mixture was allowed to stir for $20 \mathrm{~h}$ during which time a white cloudy ppt formed. The reaction mixture was filtered through Celite, the solvent removed and the resulting residue purified by flash column chromatography $(1: 2$ EtOAc:hexanes) to give the PhF-protected product (8) $(1.80 \mathrm{~g}, 62 \%)$ as a white foam. $[\alpha]^{20}{ }_{\mathrm{D}}=-33.3\left(c 0.6, \mathrm{CH}_{2} \mathrm{Cl}_{2}\right)$; IR (neat) $3313,1700,1413,1203,732,702 \mathrm{~cm}^{-1} ;{ }^{1} \mathrm{H} \mathrm{NMR}$ $\left(300 \mathrm{MHz}, \mathrm{DMSO}-d_{6}\right)(\sim 2: 1$ mixture of rotamers) $\delta 7.84-7.13(\mathrm{~m}, 18 \mathrm{H}), 5.03(\mathrm{~d}, \mathrm{~J}=$ $13.1 \mathrm{~Hz}, 0.67 \mathrm{H}), 4.98(\mathrm{~d}, \mathrm{~J}=12.7 \mathrm{~Hz}, 0.33 \mathrm{H}), 4.90(\mathrm{~d}, \mathrm{~J}=12.7 \mathrm{~Hz}, 0.33 \mathrm{H}), 4.70(\mathrm{~d}, \mathrm{~J}=$ $13.1 \mathrm{~Hz}, 0.67 \mathrm{H}), 4.22$ (br d, J = 8.9Hz, 0.33H), 4.13 (br d, J = 8.8Hz, 0.67H), 3.66-3.55 $(\mathrm{m}, 1 \mathrm{H}), 3.55(\mathrm{~s}, 2 \mathrm{H}), 3.47(\mathrm{~s}, 1 \mathrm{H}), 3.09(\mathrm{~s}, 1 \mathrm{H}), 3.04(\mathrm{~s}, 2 \mathrm{H}), 2.31-1.95(\mathrm{~m}, 3 \mathrm{H}), 1.67-$ $1.62(\mathrm{~m}, 2 \mathrm{H}), 1.51-1.08(\mathrm{~m}, 4 \mathrm{H}), 0.93(\mathrm{br} \mathrm{t}, \mathrm{J}=11.7 \mathrm{~Hz}, 1 \mathrm{H}) ;{ }^{13} \mathrm{C}$ NMR $(75.4 \mathrm{MHz}$, DMSO- $\left.d_{6}\right)(\sim 2: 1$ mixture of rotamers) $\delta 173.6,173.5,172.7,172.3,153.3,152.5,149.9$, 149.3, 149.1, 148.4, 147.1, 147.0, 139.7, 139.5, 139.4, 139.1, 136.7, 136.4, 128.2, 128.0, $127.7,127.5,127.2$, 126.9, 126.8, 126.7, 126.3, 126.0, 125.3, 120.0, 119.9, 71.2, 65.8, 65.7, 60.9, 60.7, 57.8, 55.0, 54.8, 51.8, 51.0, 36.8, 33.4, 32.6, 31.5, 31.1, 30.1, 21.0; HRMS (EI) calculated for $\mathrm{C}_{37} \mathrm{H}_{35} \mathrm{~N}_{2} \mathrm{O}_{4}\left(\mathrm{M}-\mathrm{CO}_{2} \mathrm{CH}_{3}\right)$ 571.2597, found 571.2583.

(2S,4R,7R,9R)-1-((benzyloxy)carbonyl)-7-(methoxycarbonyl)-7-(9-phenyl-9Hfluoren-9-ylamino)-octahydro-1 $\boldsymbol{H}$-indole-2-carboxylic acid (1). To a solution of (8) $(1.80 \mathrm{~g}, 2.85 \mathrm{mmol})$ in $6 \mathrm{~mL}$ THF was added a solution of $\mathrm{LiOH} \cdot \mathrm{H}_{2} \mathrm{O}(533 \mathrm{mg}, 7.12 \mathrm{mmol})$ in $6 \mathrm{~mL}$ of $\mathrm{H}_{2} \mathrm{O}$. The reaction was allowed to stir for $24 \mathrm{~h}$. It was then partitioned between $\mathrm{CH}_{2} \mathrm{Cl}_{2}$ and $1 \mathrm{M} \mathrm{HCl}$ and the aqueous portion removed. The organic layer was washed with water $(20 \mathrm{~mL})$ and the combined aqueous layer washed twice with $\mathrm{CH}_{2} \mathrm{Cl}_{2}$ (20mL). The combined $\mathrm{CH}_{2} \mathrm{Cl}_{2}$ layers were dried $\left(\mathrm{Na}_{2} \mathrm{SO}_{4}\right)$, filtered and concentrated to yield the carboxylic acid (1) $(1.50 \mathrm{~g}, 86 \%)$ as a white foam that was used without further 
purification. $[\alpha]^{20}{ }_{\mathrm{D}}=-70.4\left(c 0.5, \mathrm{CH}_{2} \mathrm{Cl}_{2}\right)$; IR (neat) $3062,1705,1413,1347,1209$, $1132,727,697 \mathrm{~cm}^{-1} ;{ }^{1} \mathrm{H}$ NMR $\left(300 \mathrm{MHz}, \mathrm{DMSO}-d_{6}\right)(\sim 2: 1$ mixture of rotamers) $\delta 7.78-$ $7.10(\mathrm{~m}, 18 \mathrm{H}), 5.02(\mathrm{~d}, \mathrm{~J}=13.1 \mathrm{~Hz}, 0.67 \mathrm{H}), 4.98(\mathrm{~d}, \mathrm{~J}=12.9 \mathrm{~Hz}, 0.33 \mathrm{H}), 4.91(\mathrm{~d}, \mathrm{~J}=$ $12.9 \mathrm{~Hz}, 0.33 \mathrm{H}), 4.69(\mathrm{~d}, \mathrm{~J}=13.0 \mathrm{~Hz}, 0.67 \mathrm{H}), 4.13(\mathrm{br} \mathrm{d}, \mathrm{J}=9.3 \mathrm{~Hz}, 0.33 \mathrm{H}), 4.02(\mathrm{br} \mathrm{d}, \mathrm{J}=$ $8.8 \mathrm{~Hz}, 0.67 \mathrm{H}), 3.64-3.54(\mathrm{~m}, 1 \mathrm{H}), 3.42$ (br s, $1 \mathrm{H}), 3.10(\mathrm{~s}, 1 \mathrm{H}), 3.04(\mathrm{~s}, 2 \mathrm{H}), 2.23-2.00$ $(\mathrm{m}, 2 \mathrm{H}), 1.98-1.94(\mathrm{~m}, 1 \mathrm{H}), 1.66-1.61(\mathrm{~m}, 2 \mathrm{H}), 1.43-1.05(\mathrm{~m}, 4 \mathrm{H}), 0.91$ (br t, J $=11.9 \mathrm{~Hz}$, $1 \mathrm{H}) ;{ }^{13} \mathrm{C}$ NMR $\left(75.4 \mathrm{MHz}, \mathrm{DMSO}-d_{6}\right)(\sim 2: 1$ mixture of rotamers $) \delta 173.7,173.3,153.3$, $152.7,150.0,149.3,149.2$, 148.5, 147.1, 147.0, 139.7, 139.4, 139.1, 136.9, 136.5, 129.0, $128.2,128.0,127.7,127.4,126.9,126.8,126.3,125.9,125.4,120.0,71.2,65.6,60.9$, 60.7, 57.9, 54.9, 54.7, 51.0, 36.8, 33.4, 31.1, 30.5, 21.0; HR-MS (EI) calculated for $\mathrm{C}_{36} \mathrm{H}_{33} \mathrm{~N}_{2} \mathrm{O}_{4}\left(\mathrm{M}-\mathrm{CO}_{2} \mathrm{CH}_{3}\right)$ 557.2440, found 557.2461.

\section{Synthesis of Oligomers}

General: Solid phase chemistry was performed using a home made manual synthesizer. Dry dichloromethane was obtained from distillation over $\mathrm{CaH}_{2}$. Anhydrous DMF was purchased from Aldrich Chemical Company. Diisopropylethyl amine (DIPEA) was distilled from ninhydrin and potassium hydroxide and stored over molecular sieves (4A). O-(7-azabenzotriazol-1-yl)-N,N,N',N'-tetramethyluronium hexafluorophosphate (HATU) was obtained from Acros. MBHA•LL $\mathrm{HCl}$ resin was purchased from NovaBiochem. All solid phase reactions were mixed by bubbling Ar through the reaction vessel and continuously kept under Ar atmosphere.

\section{Synthesis of extended three building block oligomer with tyrosine (10)}

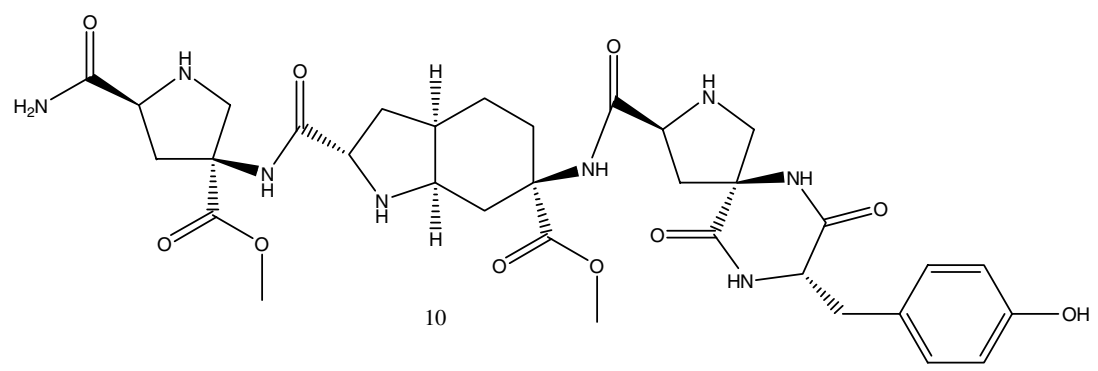

To a $5 \mathrm{~mL}$ polypropylene solid phase peptide synthesis (SPPS) reactor vessel was added MBHA LL $\cdot H C l$ Resin $(26.7 \mathrm{mg}, 16.5 \mu \mathrm{mol}$ loading). The resin was swelled for $2 \mathrm{~h}$ in dry DMF under Ar atmosphere.

To a $2.2 \mathrm{~mL}$ polypropylene microcentrifuge vial were added monomer (2) $(17.9 \mathrm{mg}$, $33 \mu \mathrm{mol})$ and HATU $(12.5 \mathrm{mg}, 33 \mu \mathrm{mol})$. DCM $(320 \mu \mathrm{L})$ and DMF $(80 \mu \mathrm{L})$ were added. DIPEA $(11.5 \mu \mathrm{L}, 660 \mu \mathrm{mol})$ was added and the solution was vortexed for $1 \mathrm{~min}$ to initiate activation of the building block. The homogeneous solution was then added immediately to the solid phase resin. The coupling reaction was mixed for $90 \mathrm{~min}$ and the solution drained from the resin. The resin was then washed twice with fresh DMF $(1 \mathrm{~mL})$ and subjected to a second coupling reaction under identical conditions. The resin was washed again with DMF $(1 \mathrm{~mL})$. The terminal Fmoc protected amine of the building block was deblocked by treatment with $20 \%$ piperidine/DMF $(2 \mathrm{~mL})$ over $40 \mathrm{~min}$. UV-visible 
spectroscopic analysis of the piperidine fluorenyl adduct from the deblocking reaction solvent at $301 \mathrm{~nm}\left(\varepsilon=7800 \mathrm{M}^{-1} \mathrm{~cm}^{-1}\right)$ revealed nearly quantitative coupling, relative to initial resin loading. The resin was washed three times with DMF $(1 \mathrm{~mL})$.

To a $2.2 \mathrm{~mL}$ polypropylene microcentrifuge tube were added monomer (1) (20.3mg, $33 \mu \mathrm{mol})$ and HATU $(12.5 \mathrm{mg}, 33 \mu \mathrm{mol})$. DCM $(320 \mu \mathrm{L})$, DMF $(80 \mu \mathrm{L})$ and DIPEA $(11.5 \mu \mathrm{L}, 660 \mu \mathrm{mol})$ were added and the solution vortexed for $1 \mathrm{~min}$ to initiate activation of the building block. The homogeneous solution was then immediately pipetted onto the solid phase resin. The coupling reaction was mixed for $90 \mathrm{~min}$ and the solution drained from the resin. The resin was then washed twice with fresh DMF $(1 \mathrm{~mL})$ and subjected to a second coupling reaction under identical conditions. The resin was washed again with DMF (1mL). The terminal PhF protected amine of the building block was deblocked by treatment with $50 \%$ TFA/DCM $(500 \mu \mathrm{L})$ over $15 \mathrm{~min}$. Release of the PhF chromophore was monitored by UV-vis spectroscopy to ensure complete deprotection. The resin was washed twice with DCM (1mL), neutralized (20\% DIPEA/DCM, $400 \mu \mathrm{L})$ and washed twice with DMF (1mL).

The above mentioned coupling and deprotection sequence for monomer (2) was performed again under identical conditions.

To a $2.2 \mathrm{~mL}$ polypropylene microcentrifuge tube were added $\mathrm{N}-\alpha$-Fmoc-O-tert-butyl-Ltyrosine $(15.1 \mathrm{mg}, 33 \mu \mathrm{mol})$, HATU $(12.5 \mathrm{mg}, 33 \mu \mathrm{mol}), \mathrm{DMF}(80 \mu \mathrm{L}), \mathrm{DCM}(320 \mu \mathrm{L})$ and DIPEA $(11.5 \mu \mathrm{L}, 660 \mu \mathrm{mol})$. The mixture was vortexed for $1 \mathrm{~min}$ to ensure activation of the amino acid and then immediately transferred to the resin. The coupling reaction was mixed for $90 \mathrm{~min}$ and the solution drained from the beads. The terminal Fmoc protected amine of the tyrosine was deblocked by treatment with $20 \%$ piperidine/DMF ( $2 \mathrm{~mL})$ over 2h. The resin was washed twice with DMF, twice with DCM, twice with methanol and twice again with DCM. The oligomer-containing resin was then dried under vacuum at room temperature overnight.

Deprotection of the Cbz groups of the oligomer, removal of the tert-butyl protecting group of the tyrosine hydroxyl and cleavage of the oligomer from the resin were done by treatment with a cleavage solution containing TFA $(500 \mu \mathrm{L})$, thioanisole $(50 \mu \mathrm{L})$, ethane dithiol $(25 \mu \mathrm{L})$ and trifluoromethane sulfonic acid $(50 \mu \mathrm{L})$ for $2.5 \mathrm{~h}$ at room temperature with magnetic stirring. The cleavage solution was drained into a centrifuge tube containing an excess volume of diethyl ether $(35 \mathrm{~mL})$, whereupon the oligomer precipitated as a yellow solid. The resin was washed with an additional portion of TFA $(250 \mu \mathrm{L})$ and that volume also drained into the ether. The solution was centrifuged (9000rpm, 30min), the supernatant decanted and the residue washed with an additional portion of ether. The yellow solid was dried in vacuo and the product purified by preparative HPLC on a Waters Delta Prep 4000 instrument with photodiode array detector $\left(10-35 \% \mathrm{MeCN}: \mathrm{H}_{2} \mathrm{O}\right.$ over $30 \mathrm{~min}$, flow $=43 \mathrm{~mL} / \mathrm{min}$, UV detection $\left.=274 \mathrm{~nm}\right)$. The product containing fractions were lyophilized to remove the solvent, yielding a fluffy white powder $(\sim 11 \mathrm{mg})$. HPLC: $\mathrm{MeCN} / \mathrm{H}_{2} \mathrm{O} 5-95 \%$ over $30 \mathrm{~min}$, flow rate $=0.30$ $\mathrm{mL} / \mathrm{min}$, UV detection $=274 \mathrm{~nm}, t_{\mathrm{R}}=7.91 \mathrm{~min}$; HR-MS $(\mathrm{ESI})$ calculated for $\mathrm{C}_{33} \mathrm{H}_{45} \mathrm{~N}_{8} \mathrm{O}_{10}$ $(\mathrm{M}+\mathrm{H})$ 713.3259, found 713.3234. 


\section{Rigidification of the oligomer (3).}

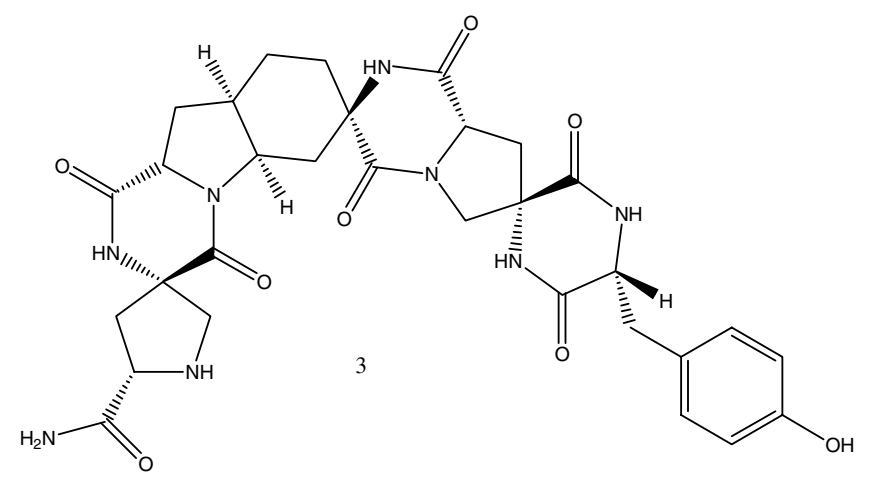

A solution of (10) in approximately $1 \mathrm{~mL}$ of $20 \%$ piperidine/DMF was incubated at $48^{\circ} \mathrm{C}$ for 10 days. The reaction progress was monitored by HPLC-MS. The reaction mixture was then added dropwise to a centrifuge vial containing an excess volume of diethyl ether $(35 \mathrm{~mL})$ to precipitate the product. The vial was centrifuged $(9000 \mathrm{rpm}, 30 \mathrm{~min})$, the supernatant decanted and the residue purified by preparative HPLC on a Waters Delta Prep 4000 instrument with photodiode array detector (10-35\% $\mathrm{MeCN}: \mathrm{H}_{2} \mathrm{O}$ over 30min, flow $=43 \mathrm{~mL} / \mathrm{min}$, UV detection $=274 \mathrm{~nm})$. The product containing fractions were lyophilized to remove the solvent, yielding a fluffy white powder $(\sim 3 \mathrm{mg})$. HPLC-MS: $\mathrm{MeCN} / \mathrm{H}_{2} \mathrm{O} 5-95 \%$ over $30 \mathrm{~min}$, flow rate $=0.30 \mathrm{~mL} / \mathrm{min}$, UV detection $=274 \mathrm{~nm}, t_{\mathrm{R}}=$ 8.19min, MS (ESI) calculated for $\mathrm{C}_{31} \mathrm{H}_{37} \mathrm{~N}_{8} \mathrm{O}_{8}(\mathrm{M}+\mathrm{H})$ 649.2, found 649.2.

\section{NMR Sample Preparation}

Approximately $1 \mathrm{mg}$ of oligomer (3) was dissolved in $332 \mu \mathrm{L}$ of 9:1 $\mathrm{H}_{2} \mathrm{O} / \mathrm{D}_{2} \mathrm{O}, 18 \mu \mathrm{L}$ of $1 \mathrm{M}\left(9: 1 \mathrm{H}_{2} \mathrm{O} / \mathrm{D}_{2} \mathrm{O}\right) \mathrm{ND}_{4} \mathrm{CD}_{3} \mathrm{CO}_{2}$ buffer and $50 \mu \mathrm{L} \mathrm{CD}_{3} \mathrm{CN}$. The 2-D NMR data was collected at $4{ }^{\circ} \mathrm{C}$. The sample was prepared in an advanced microtube matched with $\mathrm{D}_{2} \mathrm{O}$ purchased from Shigemi, Inc. Spectra were taken on a Bruker $500 \mathrm{MHz}$ instrument. 